\title{
STATE IMMUNITY BEFORE THE INTERNATIONAL COURT OF JUSTICE: JURISDICTIONAL IMMUNITIES OF THE STATE (GERMANY V ITALY)
}

\author{
Matthew McMenamin*
}

The International Court of Justice recently gave judgment in Jurisdictional Immunities of the State. The case concerned German state immunity from civil claims brought in Italian courts by victims of serious violations of international humanitarian law committed by German armed forces during World War II. The Court offered a valuable clarification of the relationship between state immunity and jus cogens norms at customary international law. The conservative reasoning was thorough and extensive and the decision is likely to ossify the evolution of state immunity.

\section{INTRODUCTION}

On 3 February 2012, the International Court of Justice (ICJ) handed down a long awaited contribution to the law of state immunity in its decision in Jurisdictional Immunities of the State. ${ }^{1}$ The case concerned German state immunity from the jurisdiction of Italian courts in claims relating to serious violations of international humanitarian law (IHL) by German armed forces during World War II. The Court, in a majority judgment ripe with conservative orthodoxy, held that Germany was entitled to state immunity. ${ }^{2}$

This is the first case in which the ICJ has directly confronted the question of state immunity. It is significant for three reasons. First, the Court employed a conservative approach to the relationship between state immunity and jus cogens norms and rejected the existence of an emerging exception to immunity in cases of serious violations of IHL. Second, the case is unique in that the Court

Submitted as part of the LLB(Hons) programme at Victoria University of Wellington. I would like to thank Alberto Costi for his generous support, supervision and time.

1 Jurisdictional Immunities of the State (Germany v Italy: Greece intervening) (Judgment) ICJ, 3 February 2012 available online at International Court of Justice "Cases" <www.icj-cij.org> [Jurisdictional Immunities of the State].

2 Subject to context, "Court" refers to the majority. 
undertook an extensive and detailed examination of state practice including decisions of municipal courts. Third, divergent conceptions of the role of the ICJ in international law were manifest in the contrasting methodology of the majority and dissenting judgments.

This article will present and critique the judgment of the ICJ. To this end, Part II will introduce the concept and history of state immunity. Part III will outline the factual and legal matrix of the case, the arguments of the parties and the decision of the ICJ. Part IV will argue that, de lege lata, or what the law is, the majority reached a correct decision as to the current customary international law of state immunity. Moreover, it will argue that the majority did so by adopting an appropriately positivist methodology. On the matter of de lege ferenda, or what the law ought to be, Part V will contend that, as a matter of policy, it would be best if states came to recognise an exception to state immunity for serious breaches of jus cogens norms if there are no alternative avenues of redress. Part VI will argue that the development of this exception in state practice is unlikely given that the judgment has the potential to ossify the customary international law of state immunity.

\section{STATE IMMUNITY: CONCEPT AND EVOLUTION}

Jurisdictional state immunity precludes the judiciary of one state from exercising jurisdiction in a legal claim to which another sovereign state is a party. ${ }^{3}$ State immunity is the immunity of the state itself as opposed to that of a state official. ${ }^{4}$ It is separate and distinct from the immunity of states from enforcement measures against them. ${ }^{5}$ It is also important to distinguish immunity from impunity and an acceptance of actions as lawful. ${ }^{6}$ This article will discuss state immunity in civil proceedings, but not the individual immunity of state officials in criminal proceedings.

The rule of state immunity initially arose from the immunity of the sovereign $;^{7}$ the King could not be sued in his own courts. ${ }^{8}$ With the development of the nation state, the fundamental principles of sovereign equality and independence came to govern interstate relations. ${ }^{9}$ State immunity derives

3 Hazel Fox The Law of State Immunity (2nd ed, Oxford University Press, Oxford, 2008) at 5.

4 Katherine Reece Thomas and Joan Small "Human Rights and State Immunity: is there Immunity from Civil Liability for Torture?" (2003) 50 NILR 1 at 20.

5 Malcolm N Shaw International Law (6th ed, Cambridge University Press, Cambridge, 2008) at 724.

6 Arrest Warrant of 11 April 2000 (Democratic Republic of the Congo v Belgium) [2002] ICJ Rep 3 at 25.

7 Lorna McGregor "Torture and State Immunity: Deflecting Impunity, Distorting Sovereignty" (2007) 18 EJIL 903 at 918 .

8 Second report on jurisdictional immunities of States and their property, by Mr Sompong Sucharitkul, Special Rapporteur [1980] YILC 199, vol 2, pt 2 at [67].

9 McGregor, above n 7, at 912. 
from these principles; as captured by the maxim par in parem non habet imperium, an equal cannot have jurisdiction over an equal. ${ }^{10}$

\section{A Absolute Immunity}

State immunity was originally considered an absolute bar on the jurisdiction of one state over another. ${ }^{11}$ Absolute state immunity received its first judicial recognition in Schooner Exchange $v$ McFaddon. ${ }^{12}$ Chief Justice Marshall of the United States Supreme Court held that "one sovereign [is] in no respect amenable to another." 13 This case provided a foundation for the acceptance of the absolute doctrine in other jurisdictions. ${ }^{14}$ The United Kingdom first affirmed the doctrine in The Parlement Belge. ${ }^{15}$

\section{B Restrictive Immunity}

State immunity is not a static doctrine and societal developments have resulted in doctrinal evolution. ${ }^{16}$ Of particular influence was the increased state activity in commercial transactions in the late 19th and early 20th centuries. This occurred in the context of a global commercial marketplace and the rise of a rights consciousness. ${ }^{17}$ States that were engaged in commercial transactions with private parties could shield themselves behind the absolute doctrine of state immunity. This created a pressing social concern that the doctrine could unfairly disadvantage private companies that transacted with states. ${ }^{18}$ As a result, a restrictive conception of state immunity developed. ${ }^{19} \mathrm{~A}$

10 Shaw, above n 5, at 697; Ian Brownlie Principles of Public International Law (7th ed, Oxford University Press, Oxford, 2008) at 325.

11 Shaw, above $\mathrm{n} 5$, at 701 .

12 Schooner Exchange v McFaddon 11 US 116 (1812).

13 At 136

14 Fox, above n 3, at 204

15 The Parlement Belge [1880] 5 PD 197 (CA). This case concerned the immunity of a delivery ship owned and operated by the Belgium King in English waters. The initial decision to deny immunity on the ground that the ship was engaged in commercial activity was reversed on appeal by reason of the independence and dignity of states. See Ernest K Bankas The State Immunity Controversy in International Law: Private Suits Against Sovereign States in Domestic Courts (Springer, Berlin, 2005) at [2.5.1] for the evolution of the absolute doctrine in the English Courts.

16 Fox, above n 3, at 2 .

17 Rosanne Van Alebeek The Immunity of States and Their Officials in International Criminal Law and International Human Rights Law (Oxford University Press, New York, 2008) at 47; Brownlie, above n 10, at 327 .

18 Leandro de Oliveira Moll "Al-Adsani v United Kingdom: State Immunity and Denial of Justice with respect to Violations of Fundamental Human Rights" (2003) 4 MJIL 561 at 566.

19 Shaw, above n 5, at 701. 
distinction was drawn between a state's acta de jure imperii, sovereign acts, and acta de jure gestionis, private or commercial acts. Immunity attached to acta de jure imperii, but not to acta de jure gestionis. ${ }^{20}$

The restrictive doctrine is now solidified in practice, ${ }^{21}$ although a common definition of the precise distinction between the two categories remains elusive. ${ }^{22}$ The legislation of jurisdictions such as the United Kingdom, ${ }^{23}$ the United States, ${ }^{24}$ Australia, ${ }^{25}$ Pakistan, ${ }^{26}$ Canada, ${ }^{27}$ South

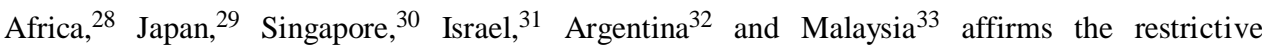
approach. While Ireland, Nigeria and Zimbabwe have not legislated on the issue, municipal judicial decisions indicate acceptance of the restrictive doctrine. ${ }^{34}$ Similarly, the New Zealand Court of Appeal held in Governor of Pitcairn and Associated Islands $v$ Sutton that a state's commercial activities are no longer protected by immunity. ${ }^{35}$ The restrictive doctrine is also accepted in civil jurisdictions such as Italy, Germany, France and Spain. ${ }^{36}$ This general acceptance is reflected in the United Nations Convention on Jurisdictional Immunities of States and Their Property (UN

20 Fox, above n 3 , at 35 .

21 At 502; Sevrine Knuchel "State Immunity and the Promise of Jus Cogens" (2011) 9 JIHR 149 at 150.

22 Paul Christoph Bornkamm "State Immunity Against Claims Arising from War Crimes: The Judgment of the International Court of Justice in Jurisdictional Immunities of the State" (2012) 13 German LJ 773 at 779

23 State Immunity Act 1978 (UK).

24 Foreign Sovereign Immunities Act 28 USC.

25 Foreign State Immunities Act 1985 (Cth).

26 State Immunity Ordinance (VI 1981).

27 State Immunity Act RSC 1985 c 18.

28 Foreign States Immunities Act 87 of 1981.

29 Act on the Civil Jurisdiction of Japan with respect to a Foreign State Law No 24 of 2009.

30 State Immunity Act 19 of 1979.

31 Foreign State Immunity Law 5769-2008.

32 Law No 24448 ADLA 1995 A 220.

33 Immunities and Privileges Act 1984.

34 Government of Canada v Employment Appeals Tribunal and Burke [1992] ILRM 325 (SC), 95 ILR 467; Kramer $v$ Government of Kingdom of Belgium and Embassy of Belgium [1989] 1 CLRQ 126 (Nigeria CA), 103 ILR 299; Baker McCormac (Private) Ltd v Government of Kenya [1983] 2 ZLR 72 (SC), 84 ILR 18

35 Governor of Pitcairn and Associated Islands $v$ Sutton [1995] 1 NZLR 426 (CA) at 428.

36 Fox, above n 3, at 223-230. 
Convention), which was adopted without a vote and, although yet to enter into force, provides an exception to immunity for commercial acts. ${ }^{37}$

The underlying justification of the restrictive doctrine is the same as that of the absolute doctrine. The principles of sovereign equality and independence require immunity with respect to sovereign acts but do not justify the same immunity with respect to non-sovereign commercial acts. ${ }^{38}$ Although state immunity manifests the principle of sovereign equality, it conflicts with the principle of territorial sovereignty and its corollary of territorial jurisdiction. Immunity derogates from territorial jurisdiction yet is an essential means by which sovereign equality of states is recognised. ${ }^{39}$

\section{Contentious Exceptions}

State immunity has continued to contract in scope as the international legal order has evolved. ${ }^{40}$ Beyond the restrictive doctrine, there is now a "twilight zone" containing further, contentious, exceptions to the absolute principle. ${ }^{41}$ Two such exceptions relevant to the discussion of the case before the ICJ are the territorial tort exception and an exception for violation of jus cogens norms.

\section{The territorial tort exception}

This exception applies to acts of a foreign state that take place in the territory of the forum state and cause death, personal injury or property damage. It is codified in both the European Convention on State Immunity and the UN Convention. ${ }^{42}$ National legislation, with the exception of Pakistan, reflects this exception. ${ }^{43}$ However, the existence and scope of this exception as a matter of customary international law remains controversial. ${ }^{44}$ The principle has developed to address the issue of insurable risks on the grounds that insurance companies should not benefit from state immunity. ${ }^{45}$ Hence, some states have limited its application to insurable risks. ${ }^{46}$ The particular issue

37 United Nations Convention on Jurisdictional Immunities of States and Their Property (opened for signature 17 January 2005, not yet in force), art 10 [UN Convention].

38 Van Alebeek, above n 17, at 49.

39 Shaw, above n 5, at 697

40 At 749.

41 Bornkamm, above n 22, at 779.

42 European Convention on State Immunity 74 ETS (opened for signature 16 May 1972, entered into force 11 June 1976), art 11; UN Convention, above n 37, art 12.

43 Jurisdictional Immunities of the State, above n 1, at [4] per Gaja J.

44 Van Alebeek, above n 17, at 69.

45 Bornkamm, above n 22, at 776.

46 At 779 
of relevance is whether this exception extends to the acts of the armed forces of a foreign state on the territory of the forum state during armed conflict. ${ }^{47}$

\section{Serious violations of jus cogens norms}

It has been contended that no immunity attaches to state acts that constitute serious violations of international law and which breach jus cogens norms. ${ }^{48}$ Jus cogens, or peremptory norms, are rules of customary international law from which no derogation is permitted and which cannot be set aside by treaty or agreement. ${ }^{49}$ In 2001, the International Law Commission identified the prohibitions of genocide, torture, slavery and the basic rules of IHL as examples of jus cogens norms. ${ }^{50}$ The contentious question is whether state immunity continues to attach to state acts that violate jus cogens norms. This question will be addressed in more detail in the following Parts of the article.

\section{JURISDICTIONAL IMMUNITIES OF THE STATE}

\section{A Factual and Legal Matrix}

The proceedings before the ICJ originated during World War II. Between 1943 and 1945, Germany occupied much of the Italian and Greek territories. During this occupation, German armed forces committed serious violations of IHL, including the massacre of civilians and the deportation of civilians and members of the Italian armed forces to slave labour camps in Germany. ${ }^{51}$ The reparation regime established following World War II was not comprehensive and many of the victims of these crimes were not eligible for compensation. ${ }^{52}$ Excluded victims advanced civil claims in both Greek and Italian courts seeking compensation from the German state. It was the

47 Roger O'Keefe "State Immunity and Human Rights: Heads and Walls, Hearts and Minds" (2011) 44 Vand J Transnatl L 999 at 1011; Christopher Keith Hall "UN Convention on State Immunity: The Need for a Human Rights Protocol" (2006) 55 ICLQ 411 at 422.

48 See for example Alexander Orakhelashvili "State Immunity and Hierarchy of Norms: Why the House of Lords Got It Wrong" (2007) 18 EJIL 955; Lorna McGregor "State Immunity and Jus Cogens" (2006) 55 ICLQ 437.

49 Brownlie, above n 10, at 510; Shaw, above n 5, at 124; Vienna Convention on the Law of Treaties 1155 UNTS 331 (opened for signature 23 May 1969, entered into force 27 January 1980), art 53:

[A] peremptory norm of general international law is a norm accepted and recognized by the international community of States as a whole as a norm from which no derogation is permitted and which can be modified only by a subsequent norm of general international law having the same character.

50 Report of the International Law Commission on the work of its fifty-third session [2001] YILC 1, vol 2, pt 2 at [40.5]; see also Shaw, above n 5, at 126; Brownlie, above n 10, at 489.

51 Jurisdictional Immunities of the State, above n 1, at [52] per the majority.

52 Bornkamm, above n 22, at 774. 
successful procession of these claims in the Italian judicial system that gave rise to the case before the ICJ.

\section{Civil proceedings before Greek courts}

In the Distomo massacre of 1944, German armed forces killed between 200 and 300 Greek civilians. ${ }^{53}$ In 2000, the Hellenic Supreme Court in Prefecture of Voiotia v Federal Republic of Germany (Prefecture of Voiotia) ordered the German state to compensate relatives of the victims of this massacre. In doing so, the Court denied the German plea of jurisdictional state immunity. ${ }^{54}$ It reasoned that the territorial tort exception in art 11 of the European Convention on State Immunity reflected customary international law. This exception applied because the acts of the armed forces breached the jus cogens norms of IHL. As such, they were rendered an abuse of sovereign power and hence were not classifiable as acta jure imperii. ${ }^{55}$ In a later factually similar case, Margellos $v$ Federal Republic of Germany (Margellos), the Greek Special Supreme Court reneged on this reasoning and held that Germany was entitled to jurisdictional immunity. ${ }^{56}$

Germany refused to comply with the decision of Prefecture of Voiotia. Enforcement proceedings failed in Greece ${ }^{57}$ and Germany. ${ }^{58}$ The European Court of Human Rights (ECtHR) also denied petitions by the victims against those states on the basis that any restriction on access to courts accorded with general international law and was, therefore, justified and proportionate. ${ }^{59}$

The Greek claimants sought to enforce the judgment in Italy where favourable jurisprudence had developed simultaneously, as discussed below. Italian courts declared the damages award enforceable in Italy. ${ }^{60}$ This led the Greek claimants to register a legal charge over German state

53 Jurisdictional Immunities of the State, above n 1, at [30] per the majority.

54 Prefecture of Voiotia v Federal Republic of Germany Hellenic Supreme Court 11, 4 May 2000, 129 ILR 513

55 Xiaodong Yang "Absolute Immunity of Foreign Armed Forces from Tort Proceedings" (2012) 71 CLJ 282 at 282; Fox, above n 3, at 583-585.

56 Margellos v Federal Republic of Germany Greek Special Supreme Court 6, 17 September 2002, 129 ILR 526.

57 The Minister for Justice did not authorise the enforcement of the judgment. Such enforcement is required under the Greek Code of Civil Procedure; Ar 923 KPolD.

58 Greek Citizens v Federal Republic of Germany (2003) NJW 3488 (BGH); 129 ILR 556.

59 Kalogeropoulou v Greece and Germany (59021/00), Section I, ECHR 12 December 2002, 129 ILR 537.

60 Repubblica Federale di Germania c Autogestione prefettizia di Voiotia Italian Court of Cassation 11163 , 12 January 2011. 
property located in Italy. ${ }^{61}$ The execution of this charge was stayed, pending the forthcoming judgment of the ICJ. ${ }^{62}$

\section{Civil proceedings before Italian courts}

The starting point of the relevant Italian jurisprudence is the 2004 decision of the Italian Court of Cassation in Ferrini v Federal Republic of Germany (Ferrini). ${ }^{63} \mathrm{Mr}$ Ferrini, an Italian civilian deported to Germany and subjected to forced labour during World War II, had advanced a civil claim against the German state. The Court found Germany was not entitled to state immunity and upheld Mr Ferrini's claim. The Court reasoned that the acts were international crimes amounting to serious violations of jus cogens norms. ${ }^{64}$ The Court considered jus cogens norms were hierarchically superior to, and therefore prevailed over, state immunity. ${ }^{65}$ The Court also emphasised Mr Ferrini's right of access to justice. To recognise immunity would be to "hinder the protection of values whose safeguard is to be considered essential to the whole international community" and would be inconsistent with a systematic interpretation of international law. ${ }^{66}$ In later cases related to deportation and forced labour, the Court of Cassation confirmed this ruling and reasoning. ${ }^{67}$

In 2008, the Court of Cassation in Germany v Milde considered a civil claim against the German state brought by the relatives of victims of civilians massacred by the German armed forces in 1944 in Cornia, Italy. ${ }^{68}$ The Court again denied state immunity for international crimes and confirmed this as a "firm point" in its jurisprudence. ${ }^{69}$ The Ferrini reasoning was reiterated. The Court stressed the need to engage in a holistic interpretation of the international public order and recognise a hierarchy of values under which fundamental human rights take priority over immunity. ${ }^{70}$

61 Jurisdictional Immunities of the State, above n 1, at [35] per the majority.

62 Bornkamm, above n 22, at 776.

63 Ferrini v Federal Republic of Germany Italian Court of Cassation 5044, 11 March 2004, (2004) 87 RDI 539, 128 ILR 659

64 At [9] and [11].

65 At [9]-[9.1].

66 At $[9.1]-[9.2]$.

67 Federal Republic of Germany v Giovanni Mantelli and others Italian Court of Cassation 14201, 29 May 2008, (2009) 134 FO 1568.

68 Germany v Milde Italian Court of Cassation 1072, 21 October 2008, (2009) 92 RDI 618.

69 At [3]-[4].

70 At [4]-[6]. 


\section{B Arguments of the Parties}

\section{Germany}

On 23 December 2008, Germany initiated proceedings against Italy before the ICJ. ${ }^{71}$ Germany alleged that Italy had violated its obligation at international law to accord Germany immunity from judicial proceedings in three ways: first, by allowing civil claims to be brought against Germany in Italian courts; second, by taking measures of constraint against German state property; and third, by declaring Greek judgments against Germany enforceable in Italy. ${ }^{72}$ In each instance, Germany argued that customary international law required jurisdictional immunity to be granted. ${ }^{73}$ Germany emphasised the limited scope of the territorial tort exception, ${ }^{74}$ and the incorrect ruling of the Italian Court of Cassation in the Ferrini jurisprudence on the relationship between state immunity and jus cogens norms. ${ }^{75}$ Germany also buttressed its position with policy arguments. It contended that a decision in favour of Italy would open the floodgates to litigants, render peace treaties meaningless, subject states to liability where liability had already been determined, and destabilise the international order. ${ }^{76}$

\section{Italy}

Italy disputed the German claim and argued it was under no obligation to accord Germany jurisdictional immunity in the circumstances. ${ }^{77}$ Italy advanced two primary arguments. First, the territorial tort exception applied to acts de jure imperii. ${ }^{78}$ Second, the circumstances and subject matter of the claims before the Italian courts justified the denial of immunity. ${ }^{79}$ Italy also emphasised that developments in international law, such as the increased relevance of the individual and of the right to access justice, had given rise to an obligation to lift state immunity if the claimant

71 Jurisdictional Immunities of the State, above n 1, at [1] per the majority.

72 At [16] per the majority.

73 Federal Republic of Germany "Memorial of the Federal Republic of Germany" (12 June 2009) International Court of Justice <www.icj-cij.org> at [115]-[130].

74 At [71]-[82].

75 At [83]-[90].

76 At [112]-[114].

77 Jurisdictional Immunities of the State, above n 1, at [38] per the majority.

78 At [62] per the majority.

79 At [80] per the majority. 
had no alternative avenues of redress. In those situations, granting immunity would be contrary to the fundamental values of the international community. ${ }^{80}$

\section{Decision of the Court}

The Court found that Italy violated its obligation to accord Germany immunity in respect of each of Germany's three claims. First, by a majority of 12 to three, the ICJ held that Italy violated its obligation by allowing civil claims to be brought against Germany. ${ }^{81}$ Judges Cançado Trindade, Yusuf, and Gaja dissented on this point. Second, by a majority of 14 to one, the ICJ held that Italy violated its obligation by taking measures of constraint against German state property. Third, the same majority held that Italy violated its obligation by declaring Greek judicial decisions against Germany enforceable in Italy. Judge Cançado Trindade dissented on both the second and third finding. ${ }^{82}$ The reasoning of the Court in each of these three claims will now be presented.

\section{Civil claims advanced in Italian courts}

The Court emphasised it was concerned with the immunity of the state itself as opposed to the immunity of individual officers of the state. ${ }^{83}$ In this way, it distinguished this case from the law relating to the immunity of state officials in criminal proceedings,${ }^{84}$ and from the judgment of the House of Lords in $R v$ Bow Street Metropolitan Stipendiary Magistrate, ex parte Pinochet Ugarte (No 3) (Pinochet). ${ }^{85}$

The Court recognised that, between the parties, state immunity was governed by international law as opposed to comity. ${ }^{86}$ As there were no applicable treaties, ${ }^{87}$ art 38(1) of the Statute of the International Court of Justice (ICJ Statute) required the Court to determine the existence of

80 Italy "Counter Memorial of Italy" (22 December 2009) International Court of Justice <www.icj-cij.org> at 61-70 and 73-78; relying, inter alia, on Basic Principles and Guidelines on the Right to a Remedy and Reparation for Victims of Gross Violations of International Human Rights Law and Serious Violations of International Humanitarian Law GA Res 60/147, A/Res/60/147 (2005) at [3.C] to support the emphasis on "effective access to justice" (emphasis added).

81 The majority on this point consisted of President Owada; Vice-President Tomka; Judges Koroma, Simma, Abraham, Keith, Sepúlveda-Amor, Bennouna, Skotnikov, Greenwood, Xue and Donoghue.

82 Jurisdictional Immunities of the State, above n 1, at [139] per the majority.

83 At [87] and [91] per the majority.

84 As addressed in Arrest Warrant of 11 April 2000 (Democratic Republic of the Congo v Belgium), above $\mathrm{n} 6$.

$85 R v$ Bow Street Metropolitan Stipendiary Magistrate, ex parte Pinochet Ugarte (No 3) [2000] 1 AC 147 (HL).

86 Jurisdictional Immunities of the State, above n 1, at [53] per the majority.

87 At [54] per the majority. 
"international custom, as evidence of a general practice accepted as law. ${ }^{88}$ The Court recalled that the criteria of a rule of customary international law included, as set out in the North Sea Continental Shelf cases, "settled practice" in combination with opinio juris. ${ }^{89}$

The Court noted that states generally accepted the restrictive doctrine of state immunity, which distinguished between acta jure gestionis and acta jure imperii. ${ }^{90}$ It acknowledged that states are "generally entitled to immunity in respect of acta jure imperii."91 The acts of the German armed forces, in the opinion of the Court, clearly constituted acta jure imperii, notwithstanding their illegality. ${ }^{92}$ The inquiry, therefore, turned to whether an exception was applicable.

(a) The territorial tort exception

The Court refrained from addressing the existence of a territorial tort exception to acta jure imperii at customary international law generally. Construing the issue narrowly, the Court focused solely on whether the tort exception negated immunity for acts committed by armed forces on the territory of the forum state during armed conflict. ${ }^{93}$ The Court addressed this question by way of a close examination of relevant state practice. International agreements, domestic legislation and municipal judicial decisions were considered. ${ }^{94}$

The only uncontested state practice in support of the application of the tort exception was Italian. Greek state practice was contrary to the Italian contention even though the Hellenic Supreme Court held in Prefecture of Voiotia that the tort exception applied to the acts of armed forces during conflict. The reason was that the Greek Special Supreme Court, in Margellos, ${ }^{95}$ had later renounced the reasoning in Prefecture of Voiotia, and accorded Germany immunity for acts of its armed forces during armed conflict even where those acts were on Greek territory. ${ }^{96}$

88 Statute of the International Court of Justice, art 38(1)(b).

89 North Sea Continental Shelf (Federal Republic of Germany v Denmark; Federal Republic of Germany $v$ Netherlands (Judgment) [1969] ICJ Rep 3 at 44.

90 Jurisdictional Immunities of the State, above n 1, at [59] per the majority.

91 At [61] per the majority.

92 At [60] per the majority; contrast with [178]-[181] per Cançado Trindade J dissenting.

93 At [64] per the majority.

94 At [66]-[76] per the majority.

95 Margellos v Federal Republic of Germany, above n 56.

96 Jurisdictional Immunities of the State, above n 1, at [83] per the majority. 
In the Court's opinion, state practice accompanied by opinio juris justified the finding that the territorial tort exception to state immunity did not apply to torts committed by armed forces during armed conflict. ${ }^{97}$

(b) The circumstances and subject matter of the claims before the Italian courts

Italy contended that the denial of immunity was justified because of the combined effect of the gravity of the offences which were the subject matter of the claims before the Italian courts, the jus cogens nature of the rules breached and the absence of alternative avenues of redress. ${ }^{98}$ The Court addressed the three strands of the Italian argument separately.

(i) The gravity of the offences

The Court held that the German acts were serious violations of the law of armed conflict and crimes under international law. ${ }^{99}$ However, the only state practice supporting an exception arising from the gravity of the offences was Italian. Moreover, state practice rejecting this exception was found in the national judicial decisions of six other states, including New Zealand. ${ }^{100}$ These decisions also revealed opinio juris by demonstrating that states have considered themselves bound by international law to reject the existence of this exception. The Court noted that the 1996 Amendment to the United States Foreign Sovereign Immunities Act removed immunity from states with respect to certain specified acts, such as torture, if those acts were performed by a state designated as a sponsor of terrorism. ${ }^{101}$ However, this legislative exception was considered an anomaly. ${ }^{102}$ The Court also referred to the absence of such a limitation in the UN Convention. This was very important in the Court's view because in 1999 the Working Group reported that the impact of serious violations of international law on the availability of immunity was "not ripe enough" to "engage in a codification exercise over it." 103 This further indicated to the Court that state practice and opinio juris did not support such an exception.

97 At [77] per the majority.

98 At [80] per the majority.

99 At [81] per the majority.

100 At [85] per the majority; Fang v Jiang [2007] NZAR 420 (HC), in which a New Zealand resident sought damages against a former President of the People's Republic of China for alleged acts of torture suffered. The Court denied the claim, reasoning that torture gave rise to an exception to the principles of state immunity.

101 Foreign Sovereign Immunities Act 28 USC §1605A.

102 Jurisdictional Immunities of the State, above n 1, at [88] per the majority.

103 At [89] per the majority. The Courts placed undue reliance on the report of the Working Group given that it significantly preceded the development of the Ferrini jurisprudence. 
The Court concluded that, as a matter of customary international law, there was no exception to state immunity where the state committed serious violations of IHL. ${ }^{104}$

(ii) Violation of jus cogens norms

Italy also argued that immunity could not shield a state from jurisdiction with respect to breaches of jus cogens norms. It submitted that jus cogens prevailed over inconsistent rules of international law, such as state immunity. The Court assumed, for the purposes of argument, that the crimes breached jus cogens. ${ }^{105}$ However, in the opinion of the Court, the rules of jus cogens and those of state immunity did not conflict: ${ }^{106}$

The rules of State immunity are procedural in character and are confined to determining whether or not the courts of one State may exercise jurisdiction in respect of another State. They do not bear upon the question of whether or not the conduct in respect of which the proceedings are brought was lawful or unlawful.

The Court considered state immunity to be procedural in nature. ${ }^{107}$ Thus, granting immunity did not equate to recognising a breach of jus cogens as lawful. ${ }^{108}$ Immunity was also an "entirely separate" issue to the international responsibility of a state and any obligation of reparation. ${ }^{109}$ Moreover, the Court found nothing inherent in the concept of jus cogens that required a denial of the rules of immunity. ${ }^{110}$

The Court also referred to judicial decisions in the United Kingdom, Canada, Poland, Slovenia, New Zealand, Greece and the ECtHR as instances in which a jus cogens exception had been denied. Once again, only Italian state practice supported the contrary position. ${ }^{111}$ Moreover, none of the domestic legislation outlined earlier limited immunity where jus cogens norms were violated. ${ }^{112}$ The Court, therefore, concluded that customary international law accorded immunity even if the acts violated jus cogens norms. ${ }^{113}$

\footnotetext{
104 At [91] per the majority.

105 At [93] per the majority.

106 At [93] per the majority.

107 At [58] per the majority.

108 At [93] per the majority.

109 At [100] per the majority.

110 At [95] per the majority.

111 At [96] per the majority.

112 At [96] per the majority.

113 At [97] per the majority.
} 
(iii) The absence of alternative redress

The third strand of the Italian argument was that removal of immunity was justified in the absence of alternative compensatory mechanisms. The Court accepted that the claimants had exhausted all their alternative avenues for redress and that granting immunity to Germany may preclude redress for the victims. ${ }^{114}$ Nevertheless, it concluded there was "no basis in state practice from which customary international law is derived" that "makes the entitlement of a State to immunity dependent upon the existence of effective alternative means of securing redress. "115

(iv) The combined effect of the arguments

Italy repeatedly emphasised during oral proceedings the unified nature of its argument: when taken together, the circumstances and subject matter of the claims before the Italian Courts justified a removal of immunity. ${ }^{116}$ The Court found that "nothing in the examination of state practice" supported that proposition and, therefore, dismissed this argument. ${ }^{117}$

\section{Measures of constraint taken against German property in Italy}

Germany's second claim alleged a breach of German state immunity from enforcement, as opposed to immunity from jurisdiction. These are separate and distinct doctrines. ${ }^{118}$ The Court held that, in the absence of express consent, a measure of constraint was only permitted over (but does not necessarily attach to) state property that is either used for commercial purposes or is specifically allocated for the satisfaction of a judicial claim. ${ }^{119}$ As the property in question was used entirely for non-commercial purposes, the legal charge violated the immunity from enforcement enjoyed by Germany under customary international law. ${ }^{120}$

\section{Declaring Greek decisions enforceable in Italy}

Germany's third claim alleged Italy breached German jurisdictional state immunity by declaring Greek decisions enforceable in Italy. The Court held that a court considering an application for the enforcement of a foreign judgment against a third state must ask whether, if the merits of the dispute had been before it, that court would have been obliged as a matter of international law to grant the

114 At [104] per the majority.

115 At [101] per the majority.

116 At [105] per the majority.

117 At [106] per the majority.

118 At [113] per the majority.

119 At [118] per the majority.

120 At [120] per the majority. 
third state immunity. ${ }^{121}$ The reasoning presented in relation to Germany's first claim therefore applied, and rendered the declaration of enforceability a violation of Germany's jurisdictional immunity. ${ }^{122}$

\section{A CRITIQUE OF THE REASONING AND METHODOLOGY}

This Part advances two primary arguments. The first concerns substance, the second concerns methodology. Thus it will be argued that, de lege lata, the Court reached the correct decision as to the current state of customary international law. It will then be argued that the majority was correct to employ a positivist methodology consisting of the thorough examination of state practice and opinio juris.

\section{A De Lege Lata: The Question of What the Law Is}

This analysis will first address the Court's discussion of the relationship between state immunity and jus cogens norms. It will then evaluate the Court's determination of the scope of customary international law by reference to state practice and opinio juris.

\section{The relationship between state immunity and jus cogens}

The Court's decision is significant for its ruling on the relationship between state immunity and jus cogens norms. Four points are to be noted. First, the Court defined a jus cogens rule as "one from which no derogation is permitted". ${ }^{123}$ This definition is not contentious. Second, the Court assumed for the purposes of argument that the violations of IHL by the German armed forces were violations of jus cogens rules. ${ }^{124}$ Third, the Court found acts that violate jus cogens norms may nevertheless constitute acta jure imperii for the purposes of the restrictive doctrine of state immunity. ${ }^{125}$ Fourth, and most importantly, the Court conceptualised rules of state immunity as procedural rather than substantive.

Points one and two require no further comment. However, points three and four are important. The decision on the third point, the scope of acta jure imperii, is important because an argument has been advanced in other settings that immunity does not apply to violations of jus cogens because they cannot be considered acta jure imperii. ${ }^{126}$ Thus the Court's decision that acts violating

121 At [130] per the majority.

122 At [131] per the majority.

123 At [95] per the majority.

124 At [93] per the majority. Although the Court indicated that at least some international humanitarian law [IHL] rules have the status of jus cogens, at [95] per the majority. Compare [98] per Cançado Trindade J dissenting: the rules of IHL at issue "belong[ed] to the domain of jus cogens."

125 At [60] per the majority, [15] per Keith J and [4] per Koroma J.

126 See Alexander Orakhelashvili Peremptory Norms in International Law (Oxford University Press, Oxford, 2006) at 326; Prefecture of Voiotia v Federal Republic of Germany, above n 54, at 521. 
international law could fall within the functions of the state was contrary to the finding of the United Kingdom House of Lords in Pinochet, and the reasoning in the Joint Separate opinion of Judges Higgins, Kooijmans and Buergenthal in Arrest Warrant of 11 April $2000{ }^{127}$ It is also one of the issues on which Judge Cançado Trindade forcefully dissented. He argued that if jus cogens norms were violated, then the distinction between acta jure imperii and acta jure gestionis became irrelevant. In his opinion, such acts were delicta imperii to which no immunity attached. ${ }^{128}$ His position was largely unsubstantiated, although it was reasoned that "a crime is a crime". ${ }^{129}$

Fourth, and most significantly, the Court was very clear that, in its opinion, rules of state immunity are procedural whereas rules of jus cogens are substantive. This distinction was drawn in response to Italy's argument that jus cogens norms prevail over conflicting rules of international law because of their hierarchical superiority. ${ }^{130}$ The Court rejected the existence of a conflict between the procedural rules of state immunity and the substantive rules of jus cogens as "the two sets of rules address different matters." 131 The Court relied upon this conceptualisation to deny an exception to state immunity arising by reason of the violation of jus cogens norms. This point was met with vigorous criticism from Judge Cançado Trindade. He critiqued the Court's reasoning as a "groundless deconstruction of jus cogens". ${ }^{32}$ For Judge Cançado Trindade, even if there was no formalistic conflict, there was a "material conflict" because immunity would deprive jus cogens norms of their legal effects. ${ }^{133}$ The argument was constructed by reference, inter alia, to the principle that "legal procedure is not an end in itself; it is a means to the realization of justice." 134 The separation of substantive and procedural law in this formalistic way would cause manifest injustice as, on these facts, it would leave victims without any alternative means of redress.

Although this article will argue that, from a legal viewpoint, the majority reached the preferable decision, the distinction between procedural and substantive law is not without its problems. It has

127 Arrest Warrant of 11 April 2000, above n 6, at 88-89; Kimberley N Trapp and Alex Mills "Smooth Runs the Water where the Brook is Deep: The Obscured Complexities of Germany v Italy" (2012) 1 CJICL 153 at 154.

128 Jurisdictional Immunities of the State, above n 1, at [213] per Cançado Trindade J dissenting.

129 At [178]-[181] per Cançado Trindade J dissenting.

130 At [92] per the majority.

131 At [93] per the majority.

132 At [296] per Cançado Trindade J dissenting.

133 At [296] per Cançado Trindade J dissenting.

134 At [295] per Cançado Trindade J dissenting. 
been labelled a "purely theoretical construct" 135 and criticised for its "excessive formalism". ${ }^{136}$ The primary motivation for such criticism appears to be the resultant de facto impunity for serious violations of jus cogens. ${ }^{137}$ To deny the existence of a conflict of norms in a situation where a procedural norm prohibits the enforcement of a right arising from a substantive norm is to adopt a restrictive interpretation of "conflict of norms". ${ }^{138}$ Yet strictly speaking there is no conflict, just mere collision. ${ }^{139}$ Moreover, it is precisely a restrictive and conservative interpretation of international law that underpins the majority's reasoning throughout. ${ }^{140}$ Whether this is an appropriate approach for the ICJ will be discussed in later Parts. For now, it ought to be noted that the distinction drawn by the majority conforms with the views of leading international law scholars and is consistent with other areas of international law and existing ICJ jurisprudence on the question.

First, the substantive/procedural distinction has been described as "one of the most fundamental concepts of legal exposition in both domestic and international law." ${ }^{141}$ It is also said to be "one of the truisms of international law." 142 It is manifested in various ways across the broader tapestry of international law. ${ }^{143}$ It is also widely accepted in the writings "of the most highly qualified publicists". ${ }^{144}$ Professor Shaw stated "the question of sovereign immunity is a procedural one". ${ }^{145}$ Similarly, Lady Hazel Fox advanced the view that: ${ }^{146}$

135 Alexander Orakhelashivili "Peremptory Norms as an Aspect of Constitutionalisation in the International Legal System" in M Frishman and S Muller (eds) The Dynamics of Constutionalism in the Age of Globalisation (TMC Asser Press, The Hague, 2010) 153 at 165.

136 McGregor, above n 7, at 911.

137 Stefan Talmon "Jus Cogens after Germany v Italy: Substantive and Procedural Rules Distinguished" (2012) 25 LJIL 979 at 981.

138 François Boudreault "Identifying Conflicts of Norms: The ICJ Approach in the Case of Jurisdictional Immunities of the State (Germany v Italy: Greece Intervening) (2012) 25 LJIL 1003 at 1007.

139 Talmon, above n 137, at 986.

140 Bornkamm, above n 22, at 773.

141 Talmon, above n 137, at 983 .

142 Antonio Cassese "When May Senior State Officials Be Tried for International Crimes? Some Comments on the Belgium v Congo case" (2002) 13 EJIL 853 at 869.

143 Talmon, above n 137, at 986-1001.

144 Statute of the International Court of Justice, above n 88, art 38(1)(d).

145 Shaw, above n 5 , at 700 .

146 Fox, above n 3, at 151 . 
State immunity is a procedural rule going to the jurisdiction of a national court. It does not go to substantive law; it does not contradict a prohibition contained in a jus cogens norm but merely diverts any breach of it to a different method of settlement.

Moreover, the ICJ has consistently adopted this conceptualisation. In Armed Activities on the Territory of the Congo, the Court held that the jus cogens nature of a rule does not confer jurisdiction on the Court where jurisdiction would not otherwise exist. ${ }^{147}$ In Arrest Warrant of 11 April 2000, the Court held that violations of norms that "undoubtedly posses[ed] the character of jus cogens,"148 did not impact the individual immunity of a Minister of Foreign Affairs because "jurisdictional immunity is procedural in nature." ${ }^{149}$ The same distinction influenced the majority of the ECtHR in Al-Adsani $v$ United Kingdom. The ECtHR in that instance held that "immunity is to be seen not as qualifying a substantive right but as a procedural bar on the national courts' power to determine" the case. ${ }^{150}$ Although these decisions are not directly on point, they indicate continued recourse to the notion of a separation between procedural and substantive rules of international law.

The Italian argument would nevertheless be persuasive if jus cogen s norms inherently contained a procedural rule guaranteeing their enforcement. This argument has been advanced by Kerstin Bartsch and Bjorn Elberling. ${ }^{151}$ It rests on the proposition that jus cogens norms create obligations erga omnes: obligations owed to all states and in respect of which all states have a legal interest. ${ }^{152}$ The authors conclude that jus cogens norms must, therefore, contain procedural elements preventing limitations to their enforcement. ${ }^{153}$ Other authors have opposed this conception of jus cogens, arguing that the universal jurisdiction arising from obligations erga omnes does not confer competence on courts which otherwise lack that competence: it merely "obliges the use of those means regularly available." 154

147 Armed Activities on the Territory of the Congo (New Application: 2002) (Democratic Republic of the Congo $v$ Rwanda) (Provisional Measures) [2006] ICJ Rep 6 at 32 and 52.

148 Jurisdictional Immunities of the State, above n 1, at [95] per the majority.

149 Arrest Warrant of 11 April 2000 (Democratic Republic of Congo v Belgium), above n 6, at 24 and 25.

150 Al-Adsani v United Kingdom (2002) 34 EHRR 11 (Grand Chamber, ECHR) at [48].

151 Kerstin Bartsch and Björn Elberling "Jus Cogens vs State Immunity; Round Two: The Decision of the European Court of Human Rights in the Kalogeropoulou et al v Greece and Germany Decision" (2003) 4 German LJ 477 at $487-488$.

152 Barcelona Traction, Light, and Power Company, Limited (Belgium v France) (Second Phase, Judgment) [1970] ICJ Rep 3 at 32.

153 Bartsch and Elberling, above n 151, at 487.

154 Van Alebeek, above n 17, at 352-354. See also Dalila Hoover "Universal Jurisdiction not so Universal: A Time to Delegate to the International Criminal Court" (2011) Cornell Law School Inter-University Graduate Student Conference Papers, Paper 52, at 9-13 for a discussion of the impact of inadequate national legislation on the enforcement of obligations erga omnes. 
The Court also rejected this approach. ${ }^{155}$ The Court is correct to deny any automatic link between a violation of jus cogens and a specific legal consequence. ${ }^{156}$ The ICJ held in East Timor that even obligations erga omnes are separate and distinct from procedural jurisdiction rules and thus cannot override such rules. ${ }^{157}$ The Court also rejected the similar argument that rights and obligations arising from the violation of jus cogens norms are of a peremptory character. Although this argument had gained traction before the Inter-American Court of Human Rights, it was not supported by state practice or accepted principle.

In confirming that the rules of state immunity and jus cogens are distinct and do not conflict, the Court made a significant contribution to the law of state immunity and jus cogens.

\section{Customary international law as determined by state practice and opinio juris}

The Court relied on an extensive survey of state practice and opinio juris. It will now be argued that the reasoning of the Court in this regard was sound.

The Court proceeded on a correct understanding of the dual elements of customary international law: state practice and opinio juris. A rule of customary international law will be recognised where state practice is "settled" among those states "whose interests are specifically affected"158 by the purported customary international law, although there is no requirement of "absolute rigorous conformity." 159 There is also the requirement of opinio juris: states must have a subjective belief that their practice is obligated under international law. ${ }^{160}$

The Court undertook a thorough, detailed and accurate analysis of state practice and opinio juris. As identified by the Court, there is almost unified state practice rejecting the applicability of the territorial tort exception to immunity for acts of armed forces during conflict. ${ }^{161}$ The Court cites equally compelling evidence that state practice denies an exception to immunity in civil claims

155 Jurisdictional Immunities of the State, above n 1, at [95] per the majority.

156 Thilo Rensmann "Impact on the Immunity of States and Their Officials" in Menno T Kamminga and Martin Scheinin (eds) The Impact of Human Rights Law on General International Law (Oxford University Press, Oxford, 2009) 151 at 161.

157 East Timor (Portugal v Australia) [1995] ICJ Rep 90 at 102.

158 North Sea Continental Shelf (Federal Republic of Germany v Denmark; Federal Republic of Germany $v$ Netherlands), above $\mathrm{n} 89$, at 43 and 44 .

159 Military and Paramilitary Activities in and against Nicaragua (Nicaragua v United States) (Merits) [1986] ICJ Rep 14 at 98.

160 Shaw, above $\mathrm{n} 5$, at 84 .

161 Jurisdictional Immunities of the State, above n 1, at [91] per the majority. 
relating to serious violations of IHL and jus cogens norms even where there are no alternative means of redress available. ${ }^{162}$

The Court is correct to point out that the only municipal jurisprudence to the contrary is that of Italy. The Greek jurisprudence ought not to be accorded significant weight because taken as a whole it refutes, rather than supports, the Italian contention. As explained earlier, this is the case even though Prefecture of Voiotia itself supports Italian state practice. ${ }^{163}$

The purported exception cannot be grounded in national legislation either. At the time of the judgment, the only exception was the United States Foreign Sovereign Immunity Act. ${ }^{164}$ Canada has since legislated to create a similar exception. ${ }^{165}$ However, the Court is correct to attach little weight to the relevance of this legislation. First, state practice is not required to be in absolute conformity. ${ }^{166}$ Moreover, the exceptions are political in nature as the only states that can be sued are those that the United States and Canadian Executives identify as sponsors of terrorism. ${ }^{167}$

In contrast to the thorough analysis provided by the Court, the dissenting judgments failed to consider the issue of state practice adequately or, in some cases, at all. For example, dissenting Judge Yusuf disagreed that state practice supported Germany's position. In his opinion, "state immunity is, as a matter of fact, as full of holes as Swiss cheese." However, no specific examples of the alleged extensive uncertainty were cited. ${ }^{168}$ It can be concluded that Judge Yusuf was overstating the matter. It is acknowledged that uncertainty as to the distinction between acta jure gestionis and acta jure imperii exists in state practice. ${ }^{169}$ However, this distinction was not at issue before the Court. With the exceptions of Italian jurisprudence and North American legislation, the state practice relating to the issues before the Court was consistent. Judge Cançado Trindade characterised state practice as "sparse". This led him to conclude that state practice could not prevent the negation of state immunity in cases of grave breaches of jus cogens. ${ }^{170}$ However, although the state practice considered by the Court is not universal, it is uniform across those states

162 At [96] per the majority.

163 At [76] per the majority.

164 Foreign Sovereign Immunities Act 28 USC §1605A.

165 Justice for Victims of Terrorism Act 2012 amending the 1985 State Immunity Act RSC 1985 c s 18.

166 Military and Paramilitary Activities in and against Nicaragua (Nicaragua v United States), above n 159, at 98.

167 Andrea Gattini "The Dispute on Jurisdictional Immunities before the ICJ: Is the Time Ripe for a Change of the Law?" (2011) 24 LJIL 173 at 174.

168 Jurisdictional Immunities of the State, above n 1, at [26] per Yusuf J.

169 Bankas, above n 15, at 95; Fox, above n 3, at 503.

170 Jurisdictional Immunities of the State, above n 1, at [294] per Cançado Trindade J dissenting. 
whose interests are specifically affected by the matter. As the ICJ held in the North Sea Continental Shelf cases, that is sufficient for the identification of customary international law. ${ }^{171}$

It is, therefore, concluded that the majority reached a correct decision as to what the law is, de lege lata.

\section{B An Evaluation of Methodology}

Dissenting Judge Cançado Trindade noted that there "seems to be an abyss separating [his] position from that of the Court's majority". ${ }^{172}$ This is particularly true with respect to the methodology of each judgment. A comparative analysis of each methodology will now be undertaken, leading to the conclusion that the positivist approach of the majority is, from a legal point of view, more appropriate than Judge Cançado Trindade's value-based dissent.

The Court reached a decision primarily by recourse to an extensive survey of relevant state practice. The methodology was systematically positivistic and source orientated. The underlying question addressed was what the law is as opposed to what the law ought to be. Judge Koroma explicitly emphasised that "the Court's judgment applies the law as it exists today." 173 The absence of modal verbs such as "ought" and "should" in the judgment also reflects this approach. The ICJ has been criticised for rarely engaging in an "extensive analysis of State practice, let alone extending that to the practice of domestic courts." 174 In this respect, the comprehensive survey of state practice and opinio juris conducted by the Court is noteworthy and ought to be commended.

Nevertheless, this positivist methodology was criticised by the dissenting judges. In particular, Judge Yusuf argued that uncertainty in the law ought not to be resolved by a "formalistic counting exercise of the sparse and conflicting decisions on the matter." 175 In his view, international law is not "a question of relative numbers." 176 Judge Cançado Trindade similarly lamented that the judgment was "over-attentive to facts and oblivious of values."177 As identified earlier, the dissenting judgments were not grounded in an analysis of state practice. Instead, as Judge Cançado Trindade recognised, they placed greater importance on recourse to "issues of principle and

171 North Sea Continental Shelf (Federal Republic of Germany v Denmark; Federal Republic of Germany $v$ Netherlands), above n 89, at 43.

172 Jurisdictional Immunities of the State, above n 1, at [228] per Cançado Trindade J dissenting.

173 At [7] per Koroma J.

174 Andre Nollkaemper "The Role of Domestic Courts in the Case Law of the International Court of Justice" (2006) 5 Chinese JIL 301 at 304; Arthur Mark Weisburd "The International Court of Justice and the Concept of State Practice" (2009) 31 U Pa J Intl L 295 at 368.

175 Jurisdictional Immunities of the State, above n 1, at [27] per Yusuf J dissenting.

176 At [24] per Yusuf J dissenting.

177 At [293] per Cançado Trindade J dissenting. 
fundamental values". ${ }^{178}$ Judge Cançado Trindade adopted an approach akin to that of natural legalism and determined the dispute by reference to values such as the realisation of justice and fairness. ${ }^{179}$ His progressive and normative assessment of the merits of the case stands in stark contrast to the approach of the majority. ${ }^{180}$

The unwillingness of the Court to engage in the progressive development of the law has surprised few international law commentators given the Court's traditionally conservative judgments. ${ }^{181}$ Yet it ought to be noted that the judicial activism manifest in Judge Cançado Trindade's dissent is neither unique nor unexpected. Although the ICJ generally avoids making decisions on the basis of advancing "large scheme purposes", judges who render separate or dissenting opinions have often adopted such a methodology. ${ }^{182}$ These judges conceive their judicial function as one of advancing public values. ${ }^{183}$ For example, Judge Manfred Lachs in 1992 characterised the ICJ as "the guardian of legality for the international community." 184 Judge Cançado Trindade's approach is not unexpected given his background as President of the InterAmerican Court of Human Rights: an institution described as unique for its humanisation and moralisation of international law. ${ }^{185}$

The starting point for Judge Cançado Trindade was that serious breaches of IHL violated jus cogens. They, therefore, generated state responsibility and an individual's right to reparation. In order to protect the ultimate principle of the realisation of justice, state immunity was refused for grave breaches of jus cogens. ${ }^{186}$ Fundamentally, he sought to "secure the ongoing evolution of international law upon humanist foundations." 187 This naturalistic methodology reflects his belief

178 At [300] per Cançado Trindade J dissenting.

179 Randy E Barnett "Toward a Theory of Legal Naturalism" (1978) 2 J Libertarian Stud 97 at 98.

180 Trapp and Mills, above n 127, at 164.

181 At 164

182 Fuad Zarbiyev "Judicial Activism in International Law - A Conceptual Framework for Analysis" (2012) 3 J Int Disp Settlement 247 at 259.

183 At 254 .

184 Questions of Interpretation and Application of the 1971 Montreal Convention arising from the Aerial Incident at Lockerbie (Libyan Arab Jamahiriya v United States of America) (Provisional Measures) [1992] ICJ Rep 3 at 26; see also Judge Christopher Weeramantry in Legality of the Threat or Use of Nuclear Weapons (Advisory Opinion) [1996] ICJ Rep 226 at 533, who referred to the "moralities of the matter and the interest of humanity."

185 Ludovic Hennebel "The Inter-American Court of Human Rights: The Ambassador of Universalism" (2011) RQDI Special Edition 57 at 76-87.

186 Jurisdictional Immunities of the State, above n 1, at [129], [227] and [297] per Cançado Trindade J dissenting.

187 At [224] per Cançado Trindade J dissenting. 
that legal positivism is "shortsighted" and an inappropriate method of resolving international legal disputes. ${ }^{188}$ In his opinion, "law and ethics go ineluctably together." ${ }^{189} \mathrm{He}$ opined that this relationship must manifest in the reasoning of the Court if the importance of fundamental human values and the attainment of justice are to be realised. ${ }^{190}$ It must be this concern that led the Judge to contend that in order to fulfill its function as "the principle judicial organ of the United Nations" the ICJ must, at times, go beyond the formal sources of international law listed in art 38(1) of the ICJ Statute. ${ }^{191}$

The suggestion that the ICJ should go beyond the wording of art 38(1) in resolving a legal dispute is open to criticism. First, the ICJ has repeatedly emphasised that its function is to state existing law and only decide on the basis of law. ${ }^{192}$ It must follow that any decision of the Court can only derive legitimacy by limiting its reasoning to the formal sources of law. Professor Shaw has noted that art 38(1) "is widely recognised as the most authoritative and complete statement as to the sources of international law." 193 There is no indication that ethics or fundamental values ought to be relevant, in and of themselves, in the resolution of a legal dispute before the ICJ. Yet, Judge Cançado Trindade's reasoning expressly incorporated ethics and was guided primarily by recourse to fundamental values.

188 At [150] per Cançado Trindade J dissenting.

189 At [289] per Cançado Trindade J dissenting.

190 At [289] per Cançado Trindade J dissenting.

191 At [149] per Cançado Trindade J dissenting.

192 Shaw, above n 5, at 1065-1066; See also Fisheries Jurisdiction (United Kingdom v Iceland) (Merits) [1974] ICJ Rep 3 at 19; Northern Cameroons (Cameroon v United Kingdom) (Preliminary Objections) [1963] ICJ Rep 15 at 33; Armed Activities on the Territory of the Congo (Democratic Republic of the Congo $v$ Uganda) (Judgment) [2005] ICJ Rep 168 at 190.

193 Shaw, above n 5, at 1065; Brownlie, above n 10, at 5; Statute of the International Court of Justice, above n 88 , art 38(1):

The Court, whose function is to decide in accordance with international law such disputes as are submitted to it, shall apply:

(a) international conventions, whether general or particular, establishing rules expressly recognised by the contesting states;

(b) international custom, as evidence of a general practice accepted as law;

(c) the general principles of law recognised by civilized nations;

(d) subject to the provisions of Article 59, judicial decisions and the teachings of the most highly qualified publicists of the various nations, as subsidiary means for the determination of rules of law. 
The ICJ ought not to be guided by a subjective evaluation of ethical values. Judge Cançado Trindade provided an example of judicial activism that is inappropriate in the ICJ given it has the primary function not of law-making but of applying law to settle disputes. ${ }^{194}$ For this reason, the positivist methodology advanced by the Court is to be commended. The ascertainment of what the law ought to be should fall outside the role of the ICJ as it is an international judicial body existing in a decentralised international legal order which accords sovereign states formal independence and equality. ${ }^{195}$

The methodology of the dissenting judgments could be legitimised by conceptualising the focus on values as an identification of "general principles of law" in accordance with art 38(1)(c). However, general principles cannot be derived from purely ethical considerations. This is because the intention of art 38(1)(c) is to "authorise the Court to apply general principles of municipal jurisprudence ... in so far as they are applicable to relations of States. ${ }^{196}$ It was not intended to create a "gateway for principles of natural law." ${ }^{197}$ Moreover, general principles were included in the ICJ Statute to serve a gap-filling function in situations where the customary law was unclear. ${ }^{198}$ The customary international law on state immunity in cases of violations of jus cogens is not unclear.

Even if conceptualised as recourse to general principles, the methodology of Judge Cançado Trindade remains only partially legitimate, and arguably unnecessary, in the current dispute. If the position at customary international law can be determined by an analysis of state practice and opinio juris, then a formal positivist approach such as that adopted by the Court in this instance is required.

\section{$V$ WHAT OUGHT THE LAW TO BE? DE LEGE FERENDA}

This Part addresses the issue of de lege ferenda: what the state of customary international law ought to be. This discussion is to be distinguished from that relating to what the Court ought to have decided, or what municipal courts ought to decide in light of the judgment. Instead, it proceeds with a reference to policy considerations and recent developments in the international legal order to propose that, in the future, the law ought to contain a narrow exception to state immunity from

194 Alan Boyle and Christine Chinkin The Making of International Law (Oxford University Press, Oxford, 2007) at 266.

195 Brownlie, above n 10, at 289; Zarbiyev, above n 182, at 270.

196 Brownlie, above n 10, at 16.

197 GJH van Hoof Rethinking the Sources of International Law (Kluwer Law and Taxation Publishers, Deventer, 1983) at 139.

198 Niels Petersen "Customary Law Without Custom? Rules, Principles, and the Role of State Practice in International Custom" (2008) 23 Am U Intl L Rev 275 at 307; Jasper Finke "Sovereign Immunity: Rule, Comity or Something Else?" (2011) 21 EJIL 853 at 873. 
jurisdiction for serious breaches of jus cogens norms where there are no alternative avenues of redress.

\section{A Policy Arguments}

Germany advanced two policy arguments rejecting the proposed exception. Both were motivated by the concern that it would undermine the stability of the international legal system. First, all peace settlements would be destabilised by the possibility of subsequent individual claims for compensation. Second, weakened states would be subject to near limitless liability. ${ }^{199}$

Neither argument withstands scrutiny. First, a removal of immunity does not, per se, confer jurisdiction on domestic courts. ${ }^{200}$ Often, it has been argued that there is a need to establish a territorial link between the cause of action and the forum state. ${ }^{201}$ Moreover, the doctrine of forum non conveniens allows courts to stay proceedings if it is more appropriate that the case be heard in another forum. ${ }^{202}$ Second, the requirement of the exhaustion of all alternative remedies would prevent the floodgates from opening and thereby mitigate the "near limitless liability." 203 This is because the resources required to exhaust all alternative avenues would necessarily prevent many otherwise eligible victims from bringing a claim. ${ }^{204}$ Third, a state may remain immune from enforcement proceedings even when subject to jurisdiction. The Court confirmed that in the absence of consent a state will be immune from enforcement unless the property at issue is used for a commercial purpose or is specifically allocated for the satisfaction of a judicial claim. ${ }^{205}$ Thus immunity from enforcement is distinct from, and far exceeds, jurisdictional immunity. ${ }^{206}$ Such immunity would prevent the destabilisation of the international order.

199 Federal Republic of Germany, above n 73, at [112]-[114].

200 Amnesty International "Germany v Italy: The Right to Deny State Immunity When Victims Have No Other Recourse" (2011, Amnesty International Publications, London) at [24]; Craig Forcese "De-immunizing Torture: Reconciling Human Rights and State Immunity" (2007) 52 McGill LJ 127 at 156

201 Donald Francis Donovan and Anthea Roberts "The Emerging Recognition of Universal Civil Jurisdiction" (2006) 100 AJIL 142 at 155; Amnesty International, above n 200, at [24].

202 Elihu Lauterpacht Aspects of the Administration of International Justice (Grotius Publications, Cambridge, 1991) at 56; Donovan and Roberts, above n 201, at 155; Amnesty International, above n 200, at [25].

203 Jurisdictional Immunities of the State, above n 1, at [6] per Judge Koroma.

204 Amnesty International, above n 200, at [27].

205 Jurisdictional Immunities of the State, above n 1, at [115]-[119] per the majority.

206 Fox, above n 3, at 56; UN Convention, above n 37, art 19. 
Moreover, the proposed exception would protect and enhance the rights of access to justice and to an effective remedy. ${ }^{207}$ It would also assist in the removal of impunity for serious violations of international law. ${ }^{208}$ Policy, therefore, supports rather than opposes the proposed exception.

\section{$B$ Developments in the International Legal Order}

The proposed exception would align state immunity with recent developments in the international legal order. This is an order that is no longer purely state-centric. Respect for state sovereignty is no longer the fundamental value of the international legal order. ${ }^{209}$ The individual has risen to prominence. ${ }^{210}$ The increasing recognition of obligations erga omnes is one example of the movement away from a conception of sovereignty as a shield by which states can avoid accountability for serious international crimes. ${ }^{211}$ In 2006 the Secretary General of the Council of Europe asserted that "international law should not regard it as contrary to the dignity or sovereign equality of nations to respond to claims against them or their agents. "212 Furthermore, the focus on collective as opposed to individual reparation for serious violations of fundamental rights has been rendered historical by the Basic Principles on the Right to a Remedy and Reparation adopted by the UN General Assembly in 2005. ${ }^{213}$ Developments such as these do not suffice to establish an emerging exception to state immunity. However, the scope and impact of state immunity ought to be re-evaluated to reflect these developments and the contemporary meaning of sovereignty given that state immunity derives from sovereignty. ${ }^{214}$ As noted by Maria Gavouneli, immunity is "a classic subject of international law in perennial need of adjustment to contemporary notions of State and the rule of law."215

207 See for example Francesco Francioni "The Right of Access to Justice under Customary International Law" in Francesco Francioni (ed) Access to Justice as a Human Right (Oxford University Press, Oxford, 2007) 47.

208 Redress Immunity $v$ Accountability: Considering the Relationship between State Immunity and Accountability for Torture and other Serious International Crimes (December 2005, The Redress Trust, London) at 4.

209 Andrea Bianchi "Immunity versus Human Rights: The Pinochet Case" (1999) 10 EJIL 237 at 272.

210 Jurisdictional Immunities of the State, above n 1, at [35], [36] and [40] per Cançado Trindade J dissenting.

211 McGregor, above n 7, at 916; Redress, above n 208, at 49.

212 "Secretary General's reports under Article 52 ECHR on the question of secret detention and transport of detainees suspected of terrorist acts, notably by or at the instigation of foreign agencies" (28 February 2006) Council of Europe <www.wcd.coe.int> at [100].

213 Bornkamn, above n 22, at 780 .

214 At 778; McGregor, above n 7, at 916; Redress, above n 208, at 49-50.

215 Maria Gavouneli State Immunity and the Rule of Law (Ant N Sakkoulas Publishers, Athens, 2001) at 19. 
The evolution of state immunity to accommodate a development in the international legal order would not be unprecedented. ${ }^{216}$ As states featured more prominently in the commercial sphere, national courts created the commercial exception and adopted the restrictive doctrine of state immunity. The normative effects of sovereignty "were reappraised to give way to basic considerations of fairness." ${ }^{217}$ A similar reappraisal ought to occur so as to protect those victims of serious breaches of jus cogens who are without alternative means of redress. Crucially, however, the commercial exception arose from state practice and not by the activism of an international judicial body. The same evolutionary process ought to occur to create an exception from immunity for violations of jus cogens in the absence of alternative remedies. Importantly, as the issue is one of customary international law, such an evolution must arise out of state practice and opinio juris, not at the prerogative of an international judiciary.

\section{THE FUTURE DEVELOPMENT OF THE LAW}

It has been observed that "state immunity is one of the fastest evolving fields of international law."218 This article will now assess the likely effect of the Court's judgment on the evolution of the proposed exception. Concurring Judge Koroma stated that the judgment does not "prevent the continued evolution of the law on State immunity" because it only applied the law as it exists today. ${ }^{219}$ Yet, the very act of measuring the current state of the law will inevitably influence its future. ${ }^{220}$ As recognised by the former President of the ICJ, Judge Higgins, "the very determination of specific disputes ... does develop international law."221

\section{A Reception of the Judgment in Italy}

The ICJ Statute provides that decisions are binding "between the parties and in respect of that particular case."222 Article 94(1) of the Charter of the United Nations places an obligation on "each Member of the United Nations ... to comply with the decision of [the Court] in any case to which it is a party". ${ }^{223}$ The decision of the ICJ binds Italy to "ensure that the decisions of its courts ... infringing the immunity which the Federal Republic of Germany enjoys under international law

216 Amnesty International "Germany v Italy: The Right to Deny State Immunity When Victims Have No Other Recourse", above n 200, at [9].

217 Knuchel, above n 21, at [53].

218 Fox, above n 3, at vii.

219 Jurisdictional Immunities of the State, above n 1, at [7] per Koroma J.

220 Markus Krajewski and Christopher Singer "Should Judges Be Front Runners? The ICJ, State Immunity and the Protection of Fundamental Human Rights" (2012) 16 Max Plank UNYB 1 at 28.

221 Boyle and Chinkin, above n 194, at 270.

222 Statute of the International Court of Justice, above n 88, art 59.

223 Charter of the United Nations, art 94. 
cease to have effect". ${ }^{224}$ However, the Court stated that the good faith of the wrongful state can be presumed and, therefore, did not formally order injunctive relief. ${ }^{225}$ The ICJ opined that "there is no reason to suppose that a State whose act or conduct has been declared wrongful by the Court will repeat that act or conduct in the future. ${ }^{\text {226 }}$ Italy's international responsibility for a violation of its legal obligations is engaged with respect to the disputed jurisprudence. ${ }^{227}$ Should Italy fail to perform its obligations under this judgment, Germany may, in accordance with art 94(2) of the Charter of the United Nations, seek the assistance of the Security Council to enforce the judgment. 228

These factors suggest that the Italian judiciary will renege on its previously "firm" position. ${ }^{229}$ This is supported by statements of the Italian Minister of Foreign Affairs that the Court's ruling confirms a principle of international law and that "Italy will open a consultation process with Germany to resolve the question of the failure to pay compensation for the Italian victims of the Nazi massacres." ${ }^{230}$ However, this reception of the judgment cannot be taken for granted. Italian courts are yet to consider the effects of an ICJ judgment on Italian law. ${ }^{231}$ Moreover, the Court of Cassation has recently confirmed that fundamental constitutional norms, such as the right to judicial redress for violations of rights, prevail over customary international law. ${ }^{232}$ Thus it is likely, although not certain, that the Italian judiciary will accord Germany state immunity in factually similar cases in the future.

\section{B Reception of the Judgment in Other States}

The jus cogens exception to state immunity only ever gained momentum in Italian jurisprudence. In light of the preceding analysis the continued development of a jus cogens exception appears unlikely. Yet, it is the reception of the judgment in domestic courts of other states that will determine the immediate future of the law of immunity.

224 Jurisdictional Immunities of the State, above n 1, at [139] per the majority.

225 At [138] per the majority.

226 At [138] per the majority.

227 At [136] per the majority.

228 Charter of the United Nations, art 94(2).

229 Germany v Milde, above n 68, at [3]-[4].

230 "Nazi Massacres: We will open a consultation with Germany on compensation, says Terzi" (7 February 2012) Ministry of Foreign Affairs <www.esteri.it>.

231 Lori Fisler Damrosch "Changing the International Law of Sovereign Immunity Through National Decisions" (2011) 44 Vand J Transnatl L 1185 at 1198.

232 Beraldini Italian Court of Constitution 73, 22 March 2001, (2001) 84 RDI 490 at [3.1]; Rac Communi di Torre Annunziata et al Italian Court of Constitution 348, 24 October 2007, (2008) 91 RDI 198 at [4.7]. 
Recourse to the judgment in domestic judicial decisions could hinder the evolution of the law by generating a "customary international legal feedback loop". ${ }^{233}$ Roger O'Keefe identified this phenomenon in the context of judgments of the ECtHR. In Al-Adsani v United Kingdom, ${ }^{234}$ and Kalogeropoulou v Greece and Germany (Kalogeropoulou), ${ }^{235}$ the ECtHR held that, as a matter of customary international law, state immunity barred jurisdiction in proceedings for compensation in respect of personal injury or death caused by the violation of international law by a foreign state. These judgments have been relied upon by almost all members of the Council of Europe as authority for the obligation to accord jurisdictional immunity in such cases. ${ }^{236}$ Consequently, future decisions of the ECtHR are likely to conclude that customary international law requires immunity in these circumstances. ${ }^{237}$ This is notwithstanding the express statement in Kalogeropoulou that the judgment "does not preclude a development in customary international law in the future."238

Domestic courts tasked with determining whether state immunity attaches to serious violations of IHL may rely on the judgment of the ICJ to find that, as a matter of customary international law, they are obliged to grant immunity. These decisions would add to the state practice of denying a jus cogens exception. This would influence future decisions as to the state of customary international law. The cycle could continue on in perpetuity.

Whether this "feedback loop" eventuates will depend on whether domestic judges are in fact influenced by the judgment of the ICJ. In general, ICJ judgments are authoritative. Professor Shaw has noted that its comments as to the state of the law "are of the highest authority." ${ }^{239}$ The United States Third Restatement of Foreign Relations Law specifies that the "judgments and opinions of the International Court of Justice are accorded great weight. "240 Reasoning by recourse to judgments of the ICJ is common in the decisions of national courts. ${ }^{241}$ Such reasoning is evident in the House of

233 O'Keefe, above n 47, at 1017.

234 Al-Adsani v United Kingdom, above n 150.

235 Kalogeropoulou v Greece and Germany, above n 59.

236 Magdalena Forowicz The Reception of International Law in the European Court of Human Rights (Oxford University Press, New York, 2010) at 312.

237 O'Keefe, above n 47, at 1017.

238 Kalogeropoulou v Greece and Germany, above n 59, at 547.

239 Shaw, above n 5, at 1065 .

240 American Law Institute Restatement of the Foreign Relations Law of the United States (3rd ed, St Paul, Minnesota, 1987), § 103(b).

241 Sarita Ordonez and David Reilly "Effect of the Jurisprudence of the International Court of Justice in National Courts" in Thomas M Franck and Gregory H Fox (eds) International Law Decisions in National Courts (Transnational Publishers, New York, 1996) 335 at 352-369. 
Lords judgment in Jones $v$ Minister of Interior of Kingdom of Saudi Arabia. ${ }^{242}$ Lord Bingham noted that in Armed Activities on the Territory of the Congo the ICJ had "made plain that a breach of [a] jus cogens norm of international law does not suffice to confer jurisdiction. "243 That persuaded Lord Bingham to find that such a breach does not "automatically override all other rules of international law." 244 With respect to the present case, the statement made by Greece that the decision "will guide Greek courts in this regard" is testimony to the influence of the ICJ over states that are not technically bound by its judgments. ${ }^{245}$

In theory then, domestic courts will look to the Court's judgment as a guide for similar cases in the future. ${ }^{246}$ Thus, the decision appears likely to abate the evolution of the law of state immunity. ${ }^{247}$ Yet, it must be remembered that in the field of state immunity the primary actors are courts, not governments. Courts, as contrasted with governments, are more likely to be guided by fundamental concerns of justice. ${ }^{248}$ As noted by Kirby J, some judges "tend to be more concerned than others about protecting human rights and fundamental freedoms. "249 Hence, domestic courts may decide to accord little weight to the decision or go to great lengths to distinguish the case on the facts. It is also possible that courts will be influenced to develop an exception to state immunity drawing on Judge Cançado Trindade's dissent. The following words of Chief Justice Hughes of the United States Supreme Court perfectly capture the nature and potential effect of Judge Cançado Trindade's dissent: $: 250$

A dissent in a court of last resort is an appeal to the brooding spirit of the law, to the intelligence of a future day, when a later decision may possibly correct the error into which the dissenting judge believes the Court to have been betrayed.

242 Jones v Minister of Interior of Kingdom of Saudi Arabia [2007] 1 AC 270.

243 At [24].

244 At [24].

245 Jurisdictional Immunities of the State, above n 1, at [18] per the majority.

246 Christian Tomuschat "The International Law of State Immunity and its Development by National Institutions" (2011) 44 Vand J Transnatl L 1105 at 1106.

247 Bornkamm, above n 22, at 782.

248 At 782 .

249 Kirby J "Dissent and the Importance of Judicial Diversity" (Speech to Institute of Judicial Studies of New Zealand, Rotorua, New Zealand, August 2005).

250 Charles Evans Hughes The Supreme Court of the United States (Garden City Publishing, New York, 1928) at 68 . 
Whether judges of the future will align with the dissenting opinion is a question that only time can answer. For the moment it can certainly be concluded that the judgment has the potential to be a powerful restraint on the evolution of the law of state immunity. ${ }^{251}$

\section{CONCLUSION}

This article has evaluated the recent decision of the ICJ in Jurisdictional Immunities of the State. The Court approached the case with a conservative and positivistic interpretation of international law. It held that customary international law continues to accord state immunity to serious violations of jus cogens norms by armed forces during conflict. The judgment is likely to influence domestic courts and, therefore, risks reinforcing the status quo and restraining the development of a jus cogens exception to state immunity. An exception to state immunity where there are no alternative means of redress for victims of serious violations of jus cogens norms would be desirable. However, it is critical that any further exception arises from state practice rather than international judicial activism. In the short term at least, the jus cogens exception to state immunity will remain governed by customary international law. The decision of the ICJ is, therefore, of utmost significance.

251 Andrea Gattini "The Dispute on Jurisdictional Immunities before the ICJ: Is the Time Ripe for a Change of the Law?" (2011) 24 LJIL 173 at 197. 
